\title{
Rancang Bangun Alat Pencuci Wortel (Daucus Carota L.)
}

\author{
Designing Carrot Washers (Daucus Carota L.) \\ Faisal Sahruddin, Program Studi Pendidikan Teknologi Pertanian, Universitas Negeri \\ Makassar. Email: faisalsahruddin94@gmail.com \\ Andi Sukainah, Program Studi Pendidikan Teknologi Pertanian, Universitas Negeri \\ Makassar, email : andisukainah@yahoo.com \\ Jamaluddin, Program Studi Pendidikan Teknologi Pertanian, Universitas Negeri Makassar. \\ Email: mamal_ptm@yahoo.co.id
}

\begin{abstract}
Abstrak
Penelitian ini bertujuan untuk merancang dan mengetahui kinerja pencuci wortel (Daucus carota L.) yaitu rata-rata penggunaan air dan waktu pada proses pencucian menggunakan alat yang dirancang. Prosedur perancangan pada penelitian ini dilakukan dengan beberapa tahapan diantaranya membuat desain alat beserta ukurannya, menyiapkan alat dan bahan perakitan dan pengadaan komponen. Uji coba alat dilakukan dengan dua tahapan yaitu uji fungsional dengan cara mengoperasikan alat pencuci wortel tanpa beban yang bertujuan untuk memastikan bahwa semua komponen pada alat berfungsi dengan baik, dan uji operasional yaitu mengoperasikan alat pencuci wortel dengan memberi beban wortel jenis chantenay sebanyak $10 \mathrm{~kg}$ yang bertujuan untuk memastikan bahwa alat dapat bekerja secara optimal. Data hasil penelitian yang diperoleh dari pengujian operasional alat pada wortel jenis chantenay sebanyak $30 \mathrm{~kg}$ dengan satu kali pengujian pada setiap $10 \mathrm{~kg}$ wortel. Lama proses pencucian pertama hingga ketiga masing-masing 48 detik, serta total penggunaan air pencucian pertama hingga pencucian ketiga yaitu 90 liter.
\end{abstract}

Kata Kunci: wortel, alat pencuci, rancang bangun, efisien

\begin{abstract}
This study aims to design and determine the performance of carrot washers (Daucus carrota L.), namely the average water use and the time of the washing process using a designed tool. The design procedure in this study was carried out with several stages including making the design of the tool and its size, preparing the tools and materials for the assembly and procurement of components. The test tool is carried out in two stages, namely functional testing by operating a carrot washing device without load which aims to ensure that all components in the tool function properly, and operational tests, namely operating a carrot washing device by giving $10 \mathrm{~kg}$ of carrot type to ensure that the tool can work optimally. Data from the research results obtained from the operational testing of the tools on the Chanten carrot as much as 30 $\mathrm{kg}$ with one test in every $10 \mathrm{~kg}$ of carrots. The duration of the first to third washing process is 48 seconds each, and the total use of the first washing water to the third washing is 90 liters.
\end{abstract}

Keywords: carrot, washing tool, build design, efficient 


\section{Pendahuluan}

Salah satu komoditas pertanian yang cukup potensial untuk mendukung arah pembangunan nasiolal dibidang pertanian adalah tanaman hortikultura. Salah satu tanaman hortikultura yang memiliki potensi yang dapat dikembangkan adalah umbi wortel. Menurut sejarahnya, tanaman wortel berasal dari Timur Tengah dan Asia Tengah. Tanaman ini ditemukan tumbuh liar sekitar 6.500 tahun yang lalu (Amiruddin, 2013).

Wortel (Daucus carrota L) merupakan salah satu jenis tanaman holtikultura yang dikonsumsi umbinya. Tingginya kandungan vitamin $\mathrm{A}$ dan vitamin $\mathrm{C}$ menyebabkan wortel dikenal sebagai bahan pangan yang bermanfaat bagi kesehatan. Keadaan ini akan mendorong usaha manusia untuk membudidayakan tanaman wortel yang bernilai ekonomis sarta keinginan untuk meciptakan alat penanganan wortel pascapanen yang efektif, efisien serta berkapasitas tinggi terhadap produk yang dihasilkan.

Wortel (Daucus carota L) adalah tumbuhan jenis sayuran umbi yang biasanya berwarna kuning kemerahan atau jingga kekuningan dengan tekstur serupa kayu, bagian yang dapat dimakan dari wortel adalah bagian umbi atau akarnya. Cadangan makanan tanaman ini disimpan didalam umbi, kulit umbi wortel tipis dan jika dimakan mentah terasa renyah dan agak manis (Munawwarah 2017).

Pembersihan adalah proses menghilangkan kotoran yang menempel pada umbi. Tujuannya untuk menghilangkan kotoran yang masih menempel pada umbi supaya umbi terlihat menarik. Selama pembersihan, usahakan umbi wortel bebas dari segala kotoran yang menempel pada umbi seperti tanah, sisa tanaman atau akar tanaman dengan cara dipangkas, setelah itu dicuci dengan air bersih secara hati-hati. Untuk mencucinya dapat dilakukan dengan cara memasukkan umbi ke dalam bak air atau disemprot dengan air bersih (Rachmat, 2006).

Penanganan produk hasil pertanian seperti mencuci bahan pangan merupakan pekerjaan yang selalu dilakukan saat pemanenan sampai produk tersebut siap untuk dikonsumsi atau diproses lebih lanjut. Pekerjaan mencuci hasil-hasil pertanian dalam jumlah yang kecil dapat dilakukan dengan menggunakan wadah, karung bekas dan alat pencuci lain. Akan tetapi, jika jumlahnya yang cukup besar dan ketersediaan air yang minim, pencucian manual menggunakan wadah membutuhkan waktu dan tenaga kerja yang cukup besar. Sehingga petani cenderung menggunakan alat pencuci wortel yang ada dipasaran untuk membantu proses pencucian tersebut, akan tetapi alat pencuci wortel yang sudah ada dipasaran masih tergolong boros dalam pemakaian air, karena air yang ada di penampungan hanya dapat dipakai dalam satu kali proses pencucian.

Menurut Saputra, W,D \& Krisyanto B (2017) bahwa perancangan mesin pencuci wortel ini mempunyai spesifikasi yakni tinggi maksimal mesin 1,2 m. Kapasitas sekali proses pencucian $10 \mathrm{~kg}$ sampai $15 \mathrm{~kg}$ dengan mesin mempunyai sistem sirkulasi air, agar air yang membawa kotoran bisa langsung keluar dan mempunyai mekanisme sikat untuk membersihkan wortel, mempunyai mekanisme yang memungkinkan petani dapat menambahkan wortel ketika proses pencucian wortel berlangsung, mempunyai mekanisme yang memudahkan pengepakan hasil wortel yang sudah bersih kembali ke dalam karung, serta mesin digerakkan manual oleh petani, sehingga waktu yang digunakan belum efisien. 
Adanya hal-hal di atas yang mendasari penulis untuk membuat sebuah penelitian yang berjudul "Rancang Bangun Alat Pencuci Wortel (Daucus carota L.)". Dengan perencanaan alat pencuci wortel yang bertujuan untuk mengefisienkan air, dan waktu yang dibutuhkan para petani untuk mencuci wortel.

Tujuan yang ingin dicapai dalam penelitian ada adalah untuk mengetahui perbandingan waktu yang dibutuhkan pada proses pencucian konvensional dengan alat serta mengetahui perbandingan air yang dibutuhkan pada proses pencucian konvensional dengan alat.

\section{Metode Penelitian}

Metode penelitian yang digunakan dalam penelitian ini adalah penelitian rekayasa atau rancang bangun, pada penelitian ini dilakukan perancangan alat pencuci wortel dengan menghitung perbandingan waktu dan penggunaan air yang dibutuhkan pada proses pencucian secara konvensional dan menggunakan alat pencuci wortel.

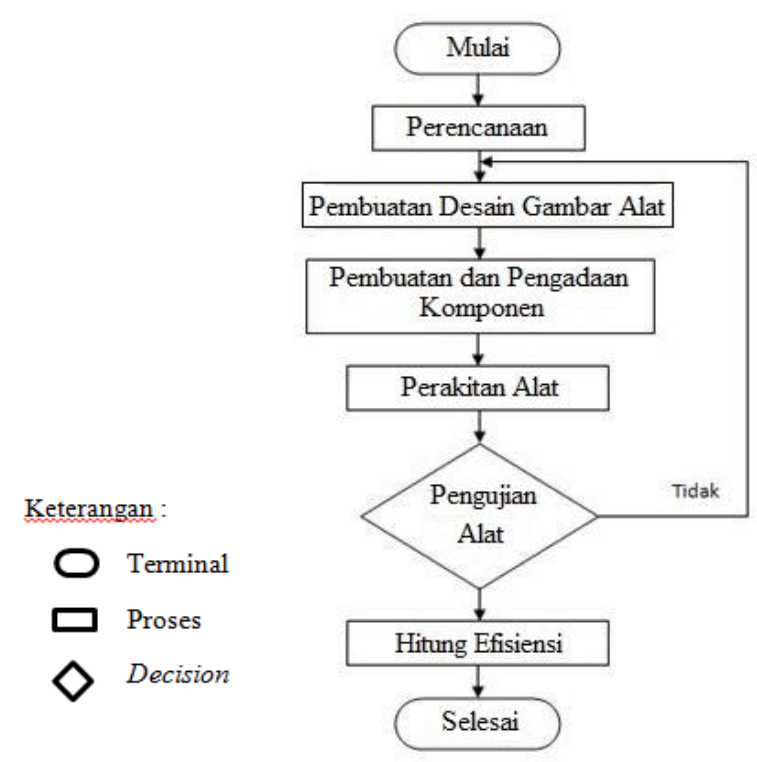

Gambar 1 Diagram alir desain penelitian

\section{Waktu Penelitian}

Penelitian ini dilakukan selama 2 bulan dengan persiapan komponen dan peralatan penunjang, pembuatan dan perakitan mesin serta penelitian lanjutan meliputi persiapan bahan untuk keperluan pengambilan data.

\section{Alat dan Bahan}

Peralatan yang digunakan pada perancangan mesin yaitu gurinda, mesin bor, roll meter, mistar ukur, las listrik, dan obeng. Bahan yang digunakan dalam perancangan mesin adalah besi siku, roda karet, plat stainless steel, bantalan (bearing), as, mur, baut, elektroda, drum 200 liter, gearbox, gear, dan rantai motor bensin $5,5 \mathrm{pk}$.

\section{Prosedur Rancang Bangun}

Prosedur perancangan pada penelitian ini dilakukan dengan beberapa tahapan diantaranya membuat desain alat beserta ukurannya, menyiapkan alat dan bahan perakitan dan pengadaan komponen.

\section{Pembuatan Desain Alat}

Pembuatan dan desain alat adalah proses membuat gambar desain produk atau alat dengan tujuan kinerja yang dicapai. Pada proses pembuatan desain alat ini digunakan beberapa software pada komputer yaitu microsoft offices word 2007 , dan Google sketchup 8.0 pro untuk memudahkan dalam perancangan desain alat yang diinginkan. Adapun gambar desain dari alat pencuci wortel sebagai berikut : 


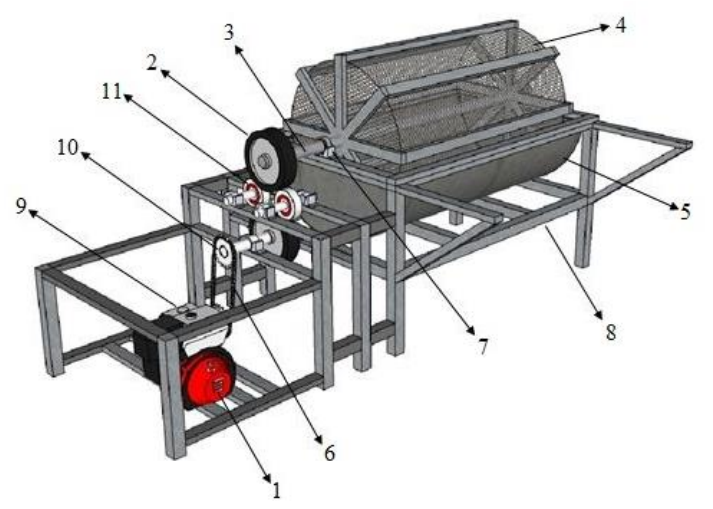

Gambar 2 Desain alat pencuci wortel Pascapanen

Keterangan :

1. Mesin penggerak utama

2. Roda karet penerus daya

3. As penampungan bahan

4. Penampungan bahan

5. Penampungan air

6. Rantai

7. Bearing

8. Rangka alat

9. Gearbox

10. Roda gigi

11. Bearing penerus daya

\section{Persiapan Alat dan Bahan}

Tahapan ini merupakan salah satu hal yang terpenting untuk membuat suatu produk atau alat. Adapun alat alat yang digunakan pada perancangan ini yaitu gerinda, mesin bor, roll meter, mistar ukur, las listrik, dan obeng. Sedangkan bahan bahan yang perlu dipersiapkan adalah besi hollow, roda karet, ram, bantalan (bearing), as, mur dan baut, elektroda, drum 200 L, gearbox, gear, rantai, dan motor bensin.

\section{Pembuatan dan Pengadaan Komponen}

Tahap ini merupakan tahapan setelah desainalat serta persiapan alat dan bahan telah ada dan lengkap. Beberapa komponen ada yang dibuat dan ada pula beberapa komponen yang dapat diperoleh secara langsung di toko seperti bantalan (bearng), as, mur dan baut, gear, gearbox, rantai, serta roda gigi. Adapun komponen yang hanya dibuat sendiri yaitu penampung wortel, dan rangka tempat komponen melekat.

Menurut Mu'minin et al. (2018) bahwa rangka aman untuk digunakan maka harus dilakukan suatu perhitungan terhadap beban yang akan dikenakan ke rangka, dimana proses pembuatan rangka dilakukan dengan cara pengelasan yang berfungsi untuk menguatkan tiap sambungan (Arhamsyah et al., 2018).

\section{Perakitan}

Perakitan dilakukan setelah alat, bahan dan komponen-komponen sudah lengkap sehingga akan memudahkan dalam proses perakitan. Adapun proses perakitan yaitu :

a. Menentukan komponen dasar pembuatan alat

b. Menggambar sketsa dari instalasi alat yang akan dibuat

c. Menyiapkan alat dan bahan yang akan digunakan dalam proses perakitan

d. Merakit instalasi dari alat sesuai dengan gambar sketsa yang telah dibuat

\section{Uji Coba Produk}

1. Menyiapkan alat dan bahan

2. Menentukan objek pengujian

3. Mengisi penampungan dengan air sebanyak 90 liter

4. Menghidupkan mesin

5. Menempatkan wortel yang baru dipanen pada penampung wortel

6. Mengoperasikan alat pencuci wortel

7. Menghitung perbandingan penggunaan air dan waktu pada proses pencucian konvensional dengan alat yang dirancang. 


\section{Teknik Analisis Data}

Teknik analisis data yang digunakan pada penelitian ini adalah teknik analisis data kuantitatif dan pengujian alat. Data yang diperoleh dari hasil uji coba ditabulasikan kedalam bentuk tabel dan diinterpretasikan secara deskriptif yang kemudian akan menjadi acuan dalam membuat deskripsi uji kerja dari alat pencuci wortel menggunakan program Microsoft Office Excel untuk menghitung nilai rata-rata dari data yang diperoleh, adapun parameter yang akan dianalisis, yaitu waktu serta jumlah air yang dibutuhkan alat dalam proses pencucian wortel dan membandingkan waktu serta jumlah air yang dibutuhkan pada proses pencucian wortel secara konvensional.

\section{Hasil dan Pembahasan}

\section{Hasil Perancangan Alat}

\section{Rangka}

Rangka utama dibuat dengan besi siku dengan ukuran $30 \mathrm{~mm}$ x $30 \mathrm{~mm}$, panjang keseluruhan rangka $1.960 \mathrm{~mm}$, lebar keseluruhan alat $1.230 \mathrm{~mm}$, tinggi keseluruhan alat $1.160 \mathrm{~mm}$. Rangka berfungsi sebagai penopang dan tempat komponen - komponen melekat (Asrianto et al. 2018).

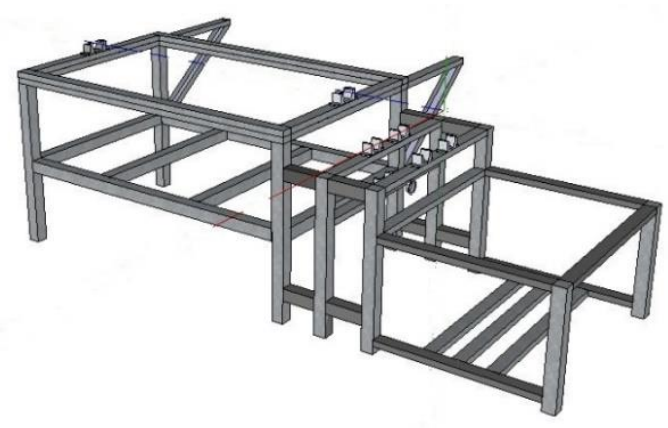

Gambar 3 Rangka

\section{Penampung Air}

Penampungan air berkapasitas $90 \mathrm{~L}$ dengan panjang $1.099 \mathrm{~mm}$, lebar penampung air $638 \mathrm{~mm}$. Penampung air berfungsi sebagai wadah untuk menampung air pada saat proses pencucian wortel.

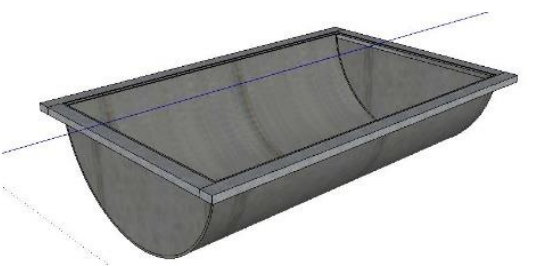

Gambar 4 Penampung air

\section{Penampung Wortel}

Penampung wortel berkapasitas 10 $\mathrm{kg}$ dengan panjang $744 \mathrm{~mm}$, lebar penampungan wortel $534 \mathrm{~mm}$. Penampung wortel berfungsi sebagai wadah untuk menampung wortel yang akan dicuci.

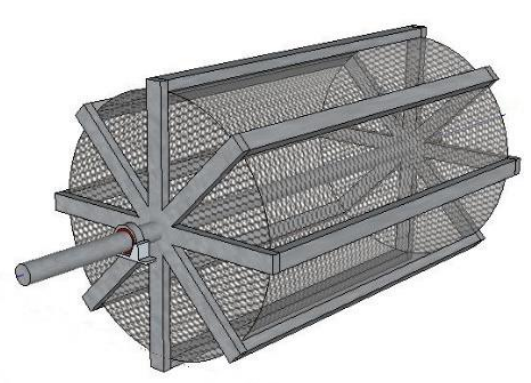

Gambar 5 Penampung Wortel

\section{Mesin Penggerak Utama Motor Bensin}

Penggerak utama motor bensin 5,5 Pk. Berfungsi sebagai mesin atau komponen penggerak utama pada proses pencucian wortel.

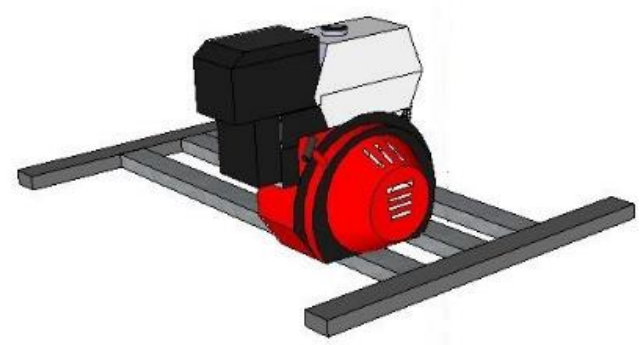

Gambar 6 Mesin Penggerak Utama 


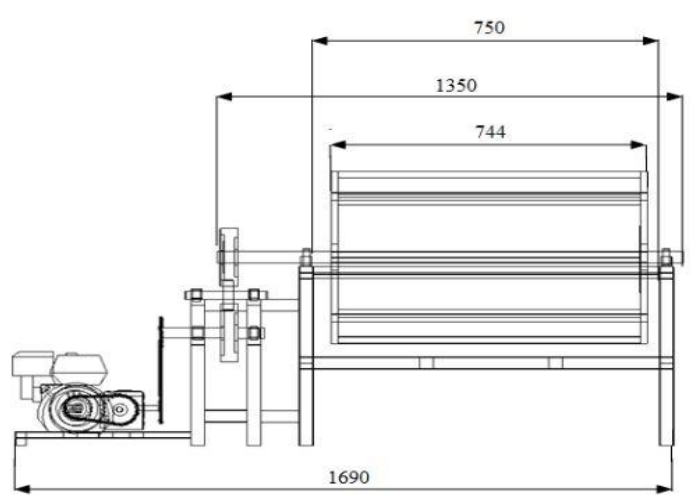

Gambar 7 Tampak Depan Alat Pencuci Wortel

\section{Hasil Uji Coba Alat}

Berikut tabel yang menunjukkan hasil pengujian rata - rata penggunaan waktu, serta kerusakan wortel pada saat pencucian secara konvensional.

Tabel 1 Hasil uji coba secara konvensional

\begin{tabular}{|c|c|c|c|}
\hline Ulangan & $\begin{array}{c}\text { Lama } \\
\text { Proses } \\
\text { Pencucian }\end{array}$ & $\begin{array}{c}\text { Kerusakan } \\
\text { Setelah } \\
\text { Pencucian }\end{array}$ & $\begin{array}{l}\text { Jumlah } \\
\text { Wortel }\end{array}$ \\
\hline I & $\begin{array}{l}2 \text { Menit } \\
3 \text { Detik }\end{array}$ & $0 \mathrm{~kg}$ & $10 \mathrm{~kg}$ \\
\hline II & $\begin{array}{l}2 \text { Menit } \\
20 \text { Detik }\end{array}$ & $0 \mathrm{~kg}$ & $10 \mathrm{~kg}$ \\
\hline III & $\begin{array}{l}2 \text { Menit } \\
33 \text { Detik }\end{array}$ & $0 \mathrm{~kg}$ & $10 \mathrm{~kg}$ \\
\hline $\begin{array}{l}\text { Rata- } \\
\text { Rata }\end{array}$ & $\begin{array}{l}2 \text { Menit } \\
18 \text { Detik }\end{array}$ & $0 \mathrm{~kg}$ & $10 \mathrm{~kg}$ \\
\hline
\end{tabular}

Sumber : Hasil Penelitian, 2019

Berdasarkan hasil pengujian secara konvensional penggunaan waktu pada ulangan I selama 2 menit 3 detik, ulangan II selama 2 menit 20 detik, ulangan III selama 2 menit 33 detik dan tidak mengalami kerusakan wortel pada saat proses pencucian. Dalam 1 kali pencucian wortel rata - rata waktu yang digunakan adalah 2 menit 18 detik dalam jumlah wortel sebanyak $30 \mathrm{~kg}$.
Tabel 2 Hasil uji coba menggunakan mesin pencuci wortel

\begin{tabular}{cccc}
\hline Ulangan & $\begin{array}{c}\text { Lama } \\
\text { Proses } \\
\text { Pencucian }\end{array}$ & $\begin{array}{c}\text { Kerusakan } \\
\text { Setelah } \\
\text { Pencucian }\end{array}$ & $\begin{array}{c}\text { Jumlah } \\
\text { Wortel }\end{array}$ \\
\hline I & 45 detik & $0 \mathrm{~kg}$ & $10 \mathrm{~kg}$ \\
II & 47 detik & $0 \mathrm{~kg}$ & $10 \mathrm{~kg}$ \\
III & 53 detik & $0 \mathrm{~kg}$ & $10 \mathrm{~kg}$ \\
\hline $\begin{array}{c}\text { Rata- } \\
\text { Rata }\end{array}$ & 48 detik & $0 \mathrm{~kg}$ & $10 \mathrm{~kg}$ \\
\hline
\end{tabular}

Sumber : Hasil Penelitian, 2019.

Berdasarkan hasil pengujian menggunakan mesin pencucian wortel, penggunaan waktu pada ulangan I selama 45 detik, ulangan II selama 47 detik, ulangan III selama 53 detik dan tidak mengalami kerusakan wortel pada saat proses pencucian. Dengan demikian, dalam 1 kali pencucian wortel rata - rata waktu yang digunakan adalah 48 detik dalam jumlah wortel sebanyak $30 \mathrm{~kg}$.

Berikut hasil jumlah penggunaan air pada saat pencucian wortel dengan cara konvensional dan menggunakan mesin pencuci wortel

Tabel 3 Jumlah penggunaan air pada saat pencucian wortel

\begin{tabular}{ccc}
\hline $\begin{array}{c}\text { Proses } \\
\text { Pencucian }\end{array}$ & $\begin{array}{c}\text { Volume Air } \\
\text { Yang } \\
\text { Digunakan } \\
(\mathbf{L})\end{array}$ & $\begin{array}{c}\text { Jumlah } \\
\text { Wortel } \\
(\mathbf{k g})\end{array}$ \\
\hline Konvensional & 208 & 30 \\
Mesin Pencuci & 90 & 30 \\
\hline
\end{tabular}

Sumber : Hasil Penelitian, 2019.

Berdasarkan hasil perhitungan jumlah penggunaan air pada saat pencucian konvensional yaitu $208 \mathrm{~L}$ per $30 \mathrm{~kg}$, sedangkan jumlah penggunaan air yang dibutuhkan pada proses pencucian dengan menggunakan mesin yaitu $90 \mathrm{~L}$ per $30 \mathrm{~kg}$. 
Beberapa keunggulan dari alat ini yaitu menghemat waktu dan tenaga kerja, penampung air yang terpisah dari penampung wortel sehingga air yang ada dalam penampungan dapat dipakai hingga tiga kali proses pencucian, menggunakan motor bensin 5,5 pk sebagai penggerak utama sehingga dapat mempercepat proses pencucian dan menghemat tenaga dalam proses pencucian.

Berdasarkan hasil penelitian sebelumnya alat yang dibuat masih dioperasikan oleh petani (manual), proses pencucian wortel memiliki kekurangan dan efek negatif terhadap hasil wortel yang dicuci. Kekurangan dan efek negatif ini di identifikasi dari kondisi wortel saat sebelum dan sesudah proses pencucian alat yang digunakan yaitu kerusakan fisik pada wortel, kerusakan fisik wortel berupa patah, lebam dan goresan yang dalam pada batang wortel, hasil pencucian yang masih meninggalkan kotoran berupa tanah, kotoran yang larut didalam air perendaman tidak mengalir terbuang, proses unloading dan packing membutuhkan waktu dan tenaga ekstra, proses pencucian melelahkan karena petani harus kontak langsung dengan air dan wortel, ada kontaminasi dari kotoran yang menempel dari kaki ke produk (Saputra, W.D. \& Krisyanto B. 2017).

\section{Simpulan}

Berdasarkan data hasil penelitian dan uji coba alat pencuci wortel (Daucus carota L.) maka disimpulkan bahwa alat yang telah dirancang berupa alat pencuci wortel dengan rangka utama dibuat dari besi siku dengan ukuran $30 \mathrm{~mm}$ x $30 \mathrm{~mm}$, mempunyai penampung air dengan volume $90 \mathrm{~L}$ dengan panjang $750 \mathrm{~mm}$ dan lebar 540 $\mathrm{mm}$, sedangkan untuk penampumn wortel terbuat dari besi hollow $30 \mathrm{~mm} \times 30 \mathrm{~mm}$ yang dilapisi dengan ram besi plat dengan panjang $744 \mathrm{~mm}$, dan lebar $534 \mathrm{~mm}$, selain itu alat pencuci wortel ini menggunakan motor bensin 5,5 pk sebagai penggerak utama dan dimensi alat dengan panjang keseluruhan $1.690 \mathrm{~mm}$, lebar keseluruhan $1.230 \mathrm{~mm}$ serta tinggi alat keseluruhan $1.160 \mathrm{~mm}$.

Nilai rata-rata penggunaan waktu pada pencucian wortel dengan cara konvensional yaitu 2 menit 18 detik per 10 $\mathrm{kg}$ sedangkan rata-rata penggunaan waktu pencucian dengan mesin pencuci yaitu 48 detik per $10 \mathrm{~kg}$ serta rata-rata kerusakan setelah pencucian masing-masing $0 \mathrm{~kg}$. Jumlah penggunaan air pada saat pencucian konvensional yaitu $208 \mathrm{~L}$ per $30 \mathrm{~kg}$, sedangkan jumlah penggunaan air yang dibutuhkan pada proses pencucian dengan menggunakan mesin yaitu $90 \mathrm{~L}$ per $30 \mathrm{~kg}$.

\section{Daftar Pustaka}

Arhamsyah, H. Syam, dan Jamaluddin. 2018. Modifikasi mesin penggering dengan memanfaatkan udara panas dari elemen pemanas listrik. Jurnal Pendidikan Teknologi Pertanian. Vol. 4 : S196-S208.

Asrianto, Jamaluddin, dan Kadirman. 2018.

Modifikasi Mesin Pengering

BijiBijian dengan Bahan Bakar Tempurung Kelapa. Jurnal Pendidikan Teknologi Pertanian. Vol. 4 : S222-S231.

Amiruddin, C. 2013. Pembuatan Tepung Wortel (Dacus carrota L) dengan Variasi Suhu Pengering. Universitas Hasanuddin. Makassar. (Skripsi)

Mu'minin MA, Caronge MW, dan Kadirman. 2018. Modifikasi Tipe Dorong untuk Memaksimalkan Pembudidayaan Wortel (Daucus carrota). Jurnal Pendidikan 
Teknologi Pertanian. Vol 4: S21-S26

UNM, Makassar

Munawwarah. 2017. Analisis Kandungan

Zat Gizi Donat Wortel sebagai

Alternatif Perbaikan Zat Gizi pada

Masyarakat. Fakultas Kedokteran

Dan Ilmu Kesehatan Universitas Islam

Negeri Alauddin Makassar.

Rachmat. M. 2006. Buku Tahunan

Hortikultura Seri Tanaman Sayuran

Jakarta (ID): Direktorat Budidaya

Tanaman Saryuran dan Biofarmaka.

Saputra, W,D \& Krisyanto. B. 2017.

Perancangan Mesin Pencuci Wortel

Manual Untuk Petani Berkapasitas

Kecil di Desa Ngargoyoso. Prosiding

Seminar Nasional Multi Disiplin Ilmu

$\&$ Call For Papers UNISBANK ke - 3

(SENDI_U3) 2017 ISBN : 9-789-

7936-499-93. 